\title{
PROGRAM PEMBERDAYAAN MASYARAKAT PESISIR BERBASIS PENDIDIKAN DI SAUBEBA-ABUN PAPUA BARAT
}

\author{
F. Pattiselanno ${ }^{1}$, A. Wondikbo ${ }^{2}$, A. Emaury ${ }^{3}$, A. Farwas ${ }^{4}$, I. Rumayomi ${ }^{5}$, \\ N. Towansiba ${ }^{6}$
}

\begin{abstract}
ABSTRAK
Sejak 2010, Universitas Papua - UNIPA secara khusus Lembaga Penelitian dan Pengabdian Pada Masayarakat (LPPM) terlibat dalam kegiatan survei, pengabdian pada masyarakat bekerja sama dengan masyarakat di Saubeba sebagai bagian dari konservasi penyu belimbing. Untuk menindak lanjuti pekerjaan UNIPA tersebut, antara bulan Juni dan Agustus 2016, sekelompok mahasiswa UNIPA melaksanakan Kuliah Kerja Nyata (KKN) di Saubeba, Distrik Abun, Kabupaten Tambrau dengan perhatian khusus pada 11 program yang dudah direncanakan bersama dengan masyarakat. Pertanian, Pengolahan Produk Pertanian, Pendidikan, Lingkungan dan Kesehatan dan juga konservasi penyu belimbing adalah program prioritas yang diperlukan. Makalah ini menyajikan sebagain program yang dikerjakan bersama dengan masyarakat khususnya dalam rangka mendukung pemberdayaan masyarakat pesisir berbasis pendidikan.
\end{abstract}

Kata Kunci: Pemberdayaan, masyarakat, pesisir, pendidikan, Papua Barat.

\begin{abstract}
Since 2010, Universitas Papua - UNIPA in particular the Research and Community Services Department was involved in survey, outreach program and collaboration works with people in Saubeba as a part of Leatherback conservation program. To follow up the work of UNIPA, between June and August 2016, a group of student from UNIPA conducted a field work in Saubeba, Abun District of Tambrauw Regency with special concerned on 11 programs that have been planned together with the communities. Agriculture, Agricultural Product Processing, Education, Environment and Health as well as Leatherback Conservation were prioritized as essential programs. This paper provides part of the program that conducted in collaboration witth local communities in order to support education-based of coastal communities empowerment.
\end{abstract}

Keywords: Empowerment, communities, coastal, education, West Papua.

\section{PENDAhUluan}

Tambrauw adalah salah satu kabuapten di kawasan Kepala Burung dengan tingkat keragaman hayati endemik tinggi, dengan luas wilayah sekitar 7.302,39 $\mathrm{Km}^{2}$ yang terdiri dari dataran seluas

\footnotetext{
${ }^{1}$ Pusat Penelitian Keanekaragaman Hayati Universitas Papua, f.pattiselanno@unipa.ac.id

${ }^{2}$ Mahasiswa Fakultas Ekonomi dan Bisnis Universitas Papua

${ }^{3}$ Mahasiswa Fakultas Teknologi Pertanian Universitas Papua

${ }^{4}$ Mahasiswa Fakultas Ekonomi dan Bisnis Universitas Papua

${ }^{5}$ Mahasiswa Fakultas Keguruan dan Ilmu Pendidikan Universitas Papua

${ }^{6}$ Mahasiswa Fakultas Teknik Pertambangan dan Perminyakan Universitas Papua
} 
5.190,67 $\mathrm{Km}^{2}$, dan lautan seluas $2.111,72 \mathrm{Km}^{2}$ memiliki potensi wilayah alam yang sangat baik. Potensi alam yang menarik dikaji di kawasan ini adalah Cagar Alam Pegunungan Tambrauw Utara, Cagar Alam Pegunungan Tambrauw Selatan, Cagar Alam Laut Pantai Sausapor dan Taman Wisata Laut Distrik Abun. Potensi Alam yang juga menjadi potensi obyek wisata di daerah ini adalah Taman Wisata Laut Distrik Abun (Pattiselanno, 2012) yang memiliki kekhasan dan keunikan tersendiri dibanding dengan daerah lain di dunia. Potensi tersebut merupakan aspek strategis daerah yang tinggi nilainya. Di Taman Wisata Laut inilah terdapat icon Kabupaten Tambrauw yang sangat langkah yaitu penyu belimbing (Dermochelys coriacea).

Sejak tahun 2009 UNIPA sebagai lembaga pendidikan tinggi lokal telah ikut terlibat dalam mengembangkan program konservasi penyu belimbing yang terus berlangsung hingga saat ini. Program pemberdayaan masyarakat yang disertai dengan pelatihan dan pendampingan berkelanjutan juga dikerjakan dengan tujuan utama meningkatkan kesejahteraan hidup masyarakat pesisir termasuk di desa-desa yang masuk dalam Kawasan Konservasi Laut Daerah seperti di Distrik Abun (Pakiding dkk., 2016).

Hal yang ingin dicapai yaitu melalui tersedianya sumber pendapatan rumah tangga alternatif berbasis ekonomi kreatif setempat, ketergantungan terhadap sumber daya hayati perburuan dan perdagangan penyu dapat dikurangi (Pattiselanno dkk., 2016). Karena itu keberlangsungan kegiatan pemberdayaan ini tetap dibutuhkan melalui pelibatan tenaga-tenaga terampil termasuk mahasiswa dengan program Kuliah Kerja Nyata (KKN) yang membantu dan terlibat langsung dalam kegiatan pemberdayaan masyarakat pesisir berkelanjutan melalui program pendidikan.

\section{METODE PELAKSANAAN}

Pelaksanaan kegiatan KKN tahun 2016 oleh mahasiswa Universitas Papua (UNIPA) dilaksanakan pada tanggal 30 Juni sampai dengan 16 Agustus 2016 di Kampung Saubeba, Distrik Abun, Kabupaten Tambrau (Gambar 2.1). Satu kelompok mahasiswa dengan latar belakang bidang ilmu yang berbeda, dibimbing oleh satu dosen pendamping lapang sekaligus ikut terlibat dalam kegiatan Pengabdian Pada Masyarakat (PPM).

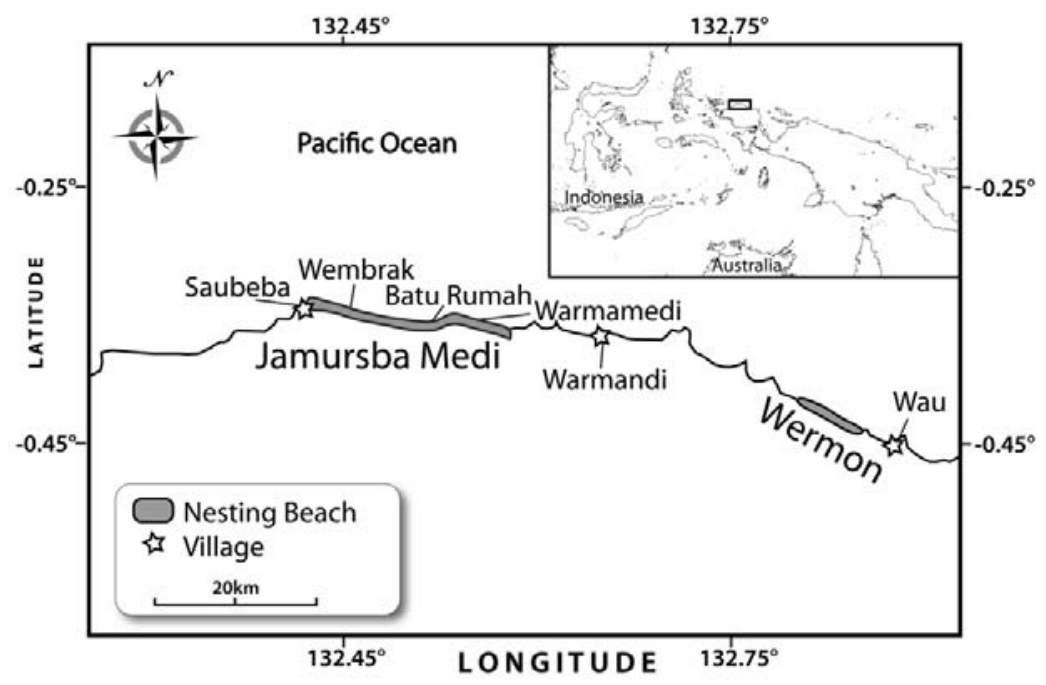

Gambar 2.1. Peta lokasi KKN di Kampung Saubeba

Sebelum terjun ke masyarakat, mahasiswa telah dibekali dengan kuliah pesangon berkaitan dengan rencana program yang dilaksanakan selama KKN. Lima orang mahasiswa yang terlibat dalam kegiatan ini sesuai dengan bidang ilmu mereka, merencanakan program kerja yang disusun sesuai 
dengan rona awal desa sasaran serta informasi yang tersedia dan permintaan pelaksanaan KKN pada bidang-bidang yang diminta oleh masyarakat. Setelah berada di lokasi, rencana pelaksanaan program kerja yang sudah disiapakan didiskusikan bersama masyarakat sekaligus mendapatkan masukan terhadap rencana program serta apa yang diusulkan oleh masyarakat dan relevan dengan kondisi desa setempat.

\section{HASIL DAN PEMBAHASAN}

\subsection{Perkenalan, Sosialisasi dan Penyusunan Program}

Setelah pertemuan secara resmi dengan masyarakat dan aparat desa, mahasiswa menyampaikan rencana program yang sudah disiapkan. Secara keseluruhan program yang diusulkan didiskusikan dengan masyarakat untuk mendapatkan persetujuan pelaksanaan bersama dengan masyarakat.

Secara detail, program kerja yang dilakukan selama kegiatan KKN yaitu bidang pertanian dan pengolahan hasil pertanian, bidang pendidikan, bidang lingkungan hidup dan kesehatan serta bidang konservasi penyu belimbing. Selain itu juga mahasiswa terlibat dalam pembangunan sarana dan prasarana umum.

\subsection{Pendidikan Formal}

Pendidikan formal dilakukan dalam bentuk mengajar di SD. YPK Lahai Roi, Desa Saubeba. Bersama dengan tim guru dan kepala sekolah, dilakukan pengidentifikasian mata ajaran yang perlu mendapat perhatian ekstra sesai dengan kebutuhan anak didik.

Hal yang paling mendasar yang dilakukan adalah memperkenalkan huruf, angka serta belajar membaca, menulis dan menghitung bagi para siswa (Gambar 3.1a dan 3.1b). Kegiatan dilaksanakan oleh para mahasiswa dengan guru mulai tanggal 25 Juli sampai dengan 13 Agustus 2016.

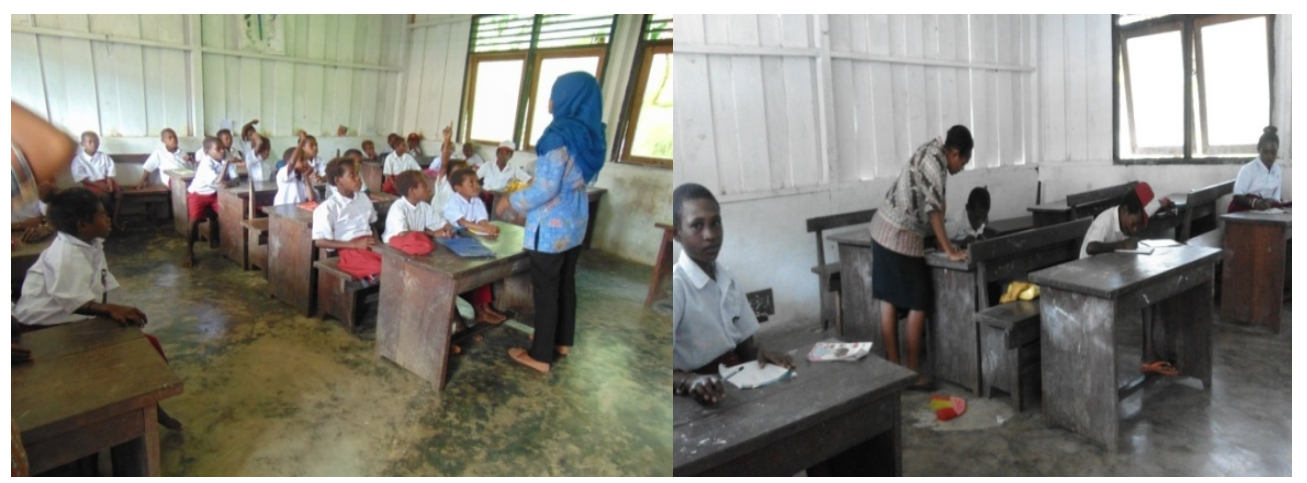

Gambar 3.1(a). Mahasiswa membantu proses belajar mengajar di kelas; 3.1(b). Membantu murid belajar menulis

Secara sederhana, diagram tulang ikan (Gambar 3.2), digunakan untuk menggambarkan kondisi awal, faktor penghambat dan pendukung, capaian dari terobosan yang dilakukan oleh mahasiswa KKN. 

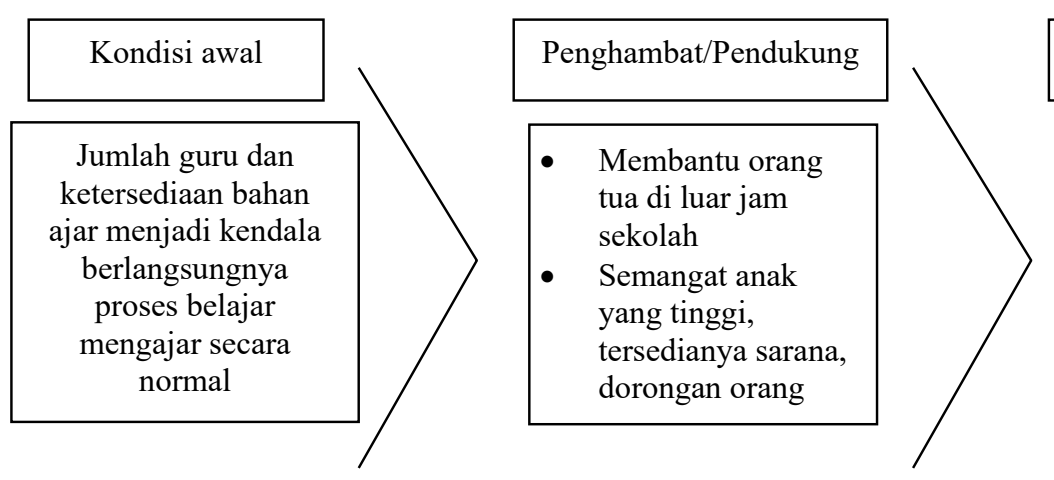

Capaian yang diperoleh

- Pengenalan dan kemampuan menulis huruf dan angka meningkat.

- Penularan hal positif kepada anak yang lain

Gambar 3.2. Deskripsi kondisi awal dan capaian yang diperoleh dari program pendidikan formal

Secara keseluruhan kegiatan pendidikan formal ini turut membantu para guru yang terbatas jumlahnya. Di sisi lain pelibatan mahasiswa KKN dalam proses belajar mengajar di sekolah memberikan dorongan kepada masyarakat tentang arti pentingnya pendidikan bagi anak-anak. Animo anak-anak untuk belajar cukup tinggi terlihat dari keikut sertaan mereka dalam setiap kegaiatan yang dilakukan oleh mahasiswa KKN.

\subsection{Pendidikan Non-formal}

Selain membantu pendidikan formal di sekolah, mahasiswa KKN juga terlibat dalam pendidikan non-formal, meliputi pemberian tambahan waktu belajar di luar sekolah yaitu di Posko KKN yang sekaligus berfungsi sebagai rumah belajar (Gambar 3.3a dan 3.3b). Pelaksanaan belajar di luar waktu sekolah dilaksanakan mulai tanggal 11 Juli sampai dengan 13 Agustus 2017. Kegiatan dilakukan di sore hari antara jam empat sampai enam sore diikuti oleh 8-15 orang siswa setiap pertemuannya dengan rataan kehadiran siswa per minggu seperti pada Grafik 3.1.

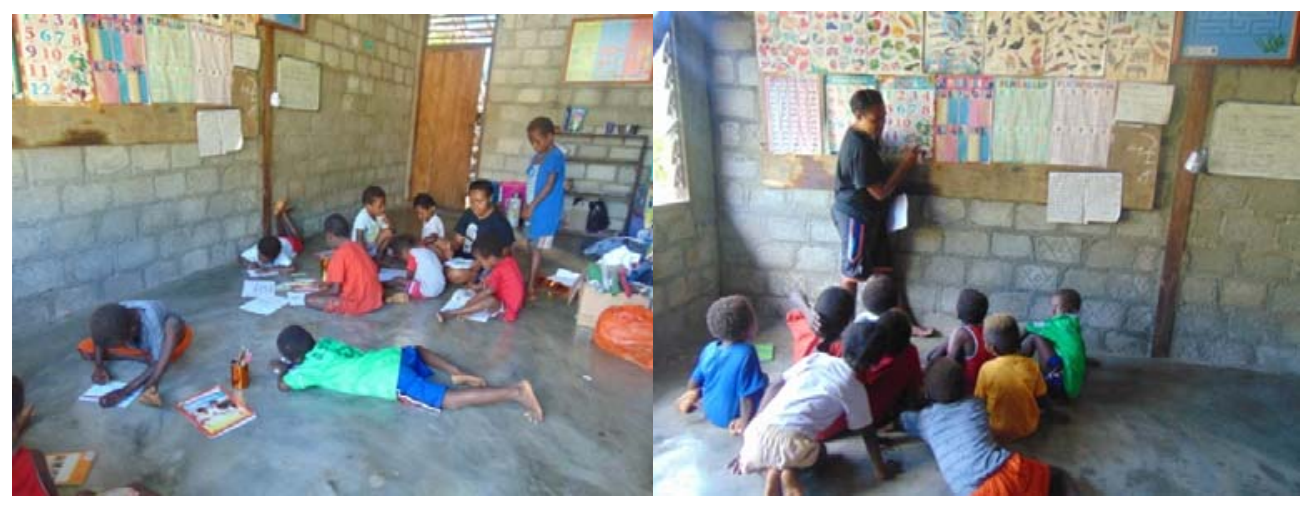

Gambar 3.3(a). Suasana belajar di rumah belajar; 3.3(b). Para siswa serius memperhatikan huruf dan angka yang dipelajari

Buku bacaan dan sarana belajar lainnya disiapkan oleh para mahasiswa dan bantuan yang diberikan oleh para donatur, dan para murid hanya mempersiapkan diri untuk mengikuti kegiatan tersebut. Mahasiswa terlibat secara bergilir dalam kegiatan belajar mengajar di luar jam sekolah tersebut.

Membantu mengasuh Sekolah Minggu setiap hari Minggu juga termasuk dalam pendidikan non-formal dengan tujuan membantu para siswa untuk lebih mendekatkan diri pada ajaran agama. Kegiatan dilakukan setiap hari Minggu pagi dan kerjasama dilakukan dengan Majelis Jemaat gereja setempat. 


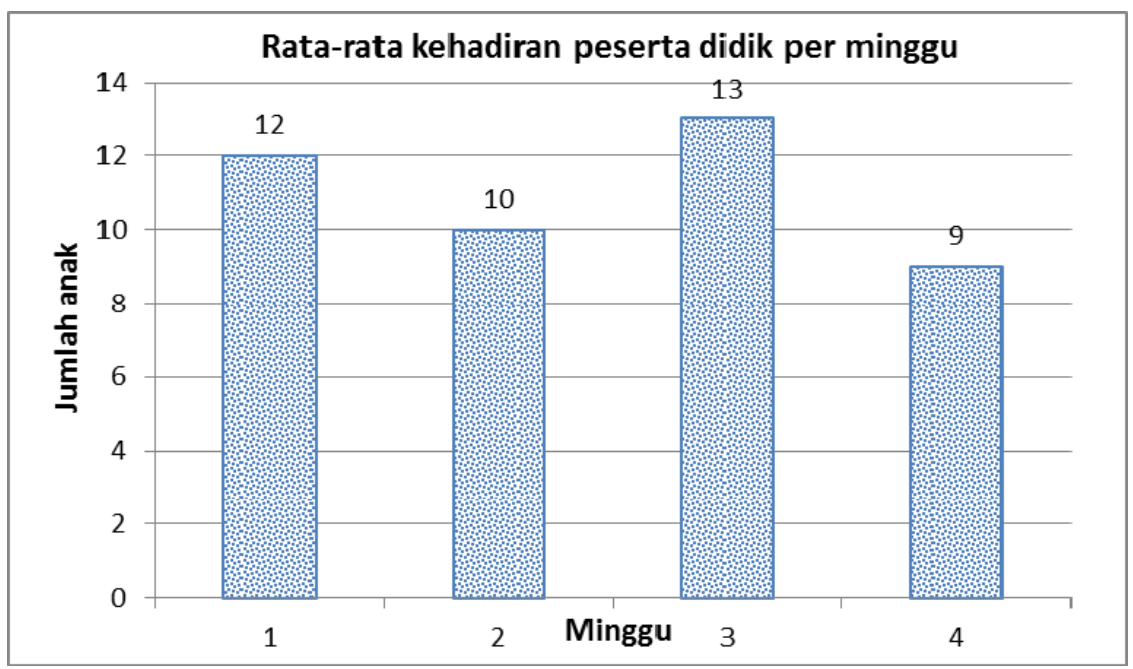

Grafik 3.1. Rata-rata kehadiran peserta didik per minggu selama kegiatan pendidikan non-formal dilaksanakan

Pendidikan non-formal di luar jam sekolah memang terkendala kehadiran peserta didik. Hal ini disebabkan karena setelah jam sekolah anak-anak harus ikut membantu orang tua dalam kegiatan bercocok tanam di kebun sekitar kampong. Pendekatan yang baik melalui kerjasama dengan tokoh masyarakat dan tokoh agama ikut membantu kehadiran anak-anak dalam bidang pendidikan non-formal.

\subsection{Pendidikan Kesehatan dan Sanitasi Lingkungan}

Program pendidikan kesehatan dan sanitasi lingkungan bertujuan untuk meningkatkan kesadaran warga desa khususnya anak-anak akan pentingnya hidup sehat dan menjaga kebersihan lingkungan sekitar. Kegiatan menjaga kesehatan yang langsung menyentuh anak-anak dan dilakukan sambil bercerita dan bermain yaitu menjaga kebersihan kuku dan memelihara kebersihan gigi.

Dalam kegiatan ini anak-anak diajak untuk memelihara kebersihan kuku (Gambar 3.4a), dan dilakukan pelayanan gunting kuku bagi mereka yang mempunyai kuku yang panjang dan kotor. Sedangkan program sikat gigi bersama (Gambar 3.4b) dilakukan di pagi hari dengan contoh langsung oleh mahasiswa dan diikuti oleh anak-anak.

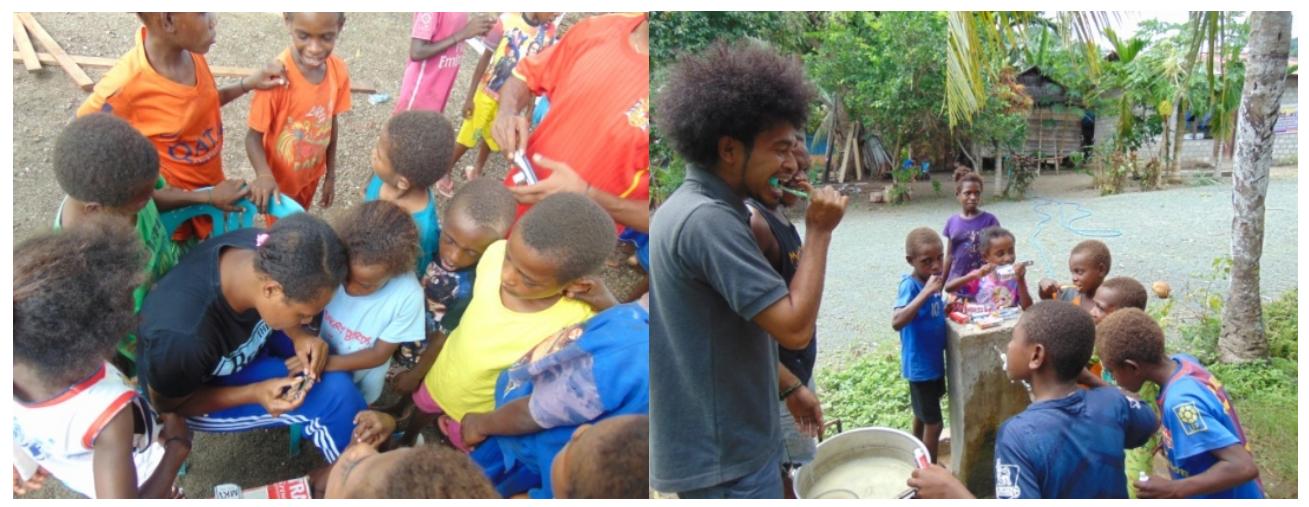

Gambar 3.4(a). Program kebersihan kuku bagi anak-anak; 3.4(b). Menjaga kebersihan gigi dan mulut melalui program sikat gigi bersama anak-anak 
Walaupun program hanya dilakukan satu hari saja, tetapi anak-anak sangat antusias ikut terlibat dan sekitar 50 orang anak ikut mengambil bagian dalam kegiatan ini. Setelah pelaksanaan kegiatan anak-anak tetap terus diingatkan bahkan selalu diajak bersama untuk menjaga kebersihan kuku dan gigi. Tidak jarang mereka dating ke posko KKN, meminta bantuan para mahasiswa menggunting kuku dan menyikat gigi. Guna menjaga keberlangsung kegiatan ini setelah program KKN berakhir, kerjasama dengan puskesmas setempat telah dijalin terlebih dahulu. Dalam kunjungan ke Saubeba sebulan setelah kegiatan KKN berakhir, sekitar $85 \%$ dari anak yang mengikuti program ini masih terus aktif menjaga kebersihan kuku dan gigi mereka.

Kebersihan lingkungan memainkan peranan penting untuk menciptakan suasana dan keadaan bersih di kampong. Oleh karena itu dalam program sanitasi lingkungan, warga kampung diajak berpartisipasi dalam program kebersihan (Gambar 3.5a dan 3.5b). Kegiatan dilakukan setiap hari Jumat dalam minggu berjalan dengan slogan "Jumat Bersih".

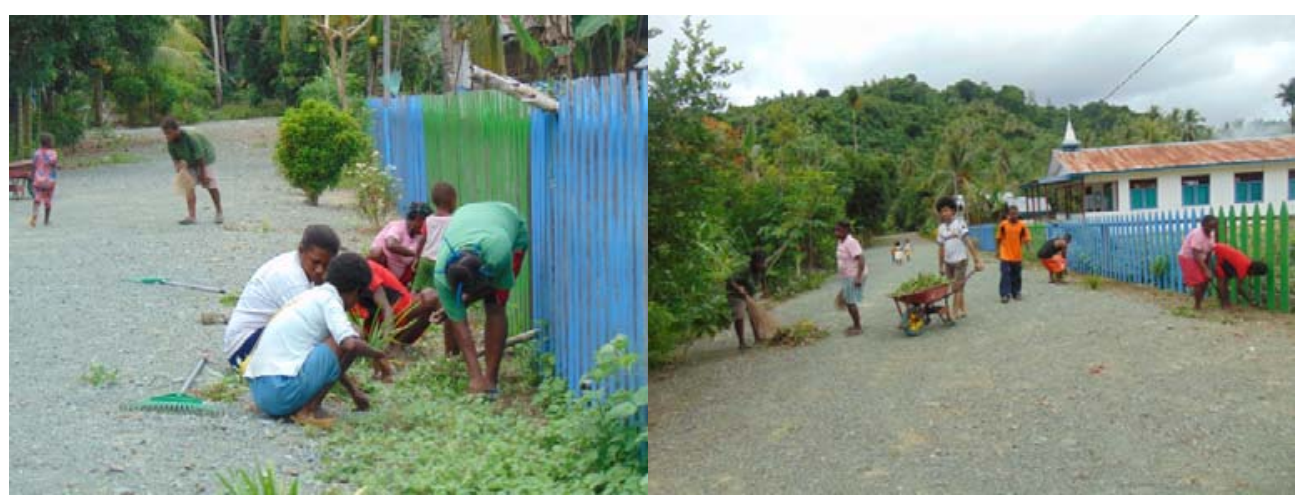

Gambar 3.5(a). Menjaga kebersihan lingkungan bersama-sama; 3.5(b). Semua warga kampung ikut terlibat dalam kegiatan Jumat Bersih

Animo masyarakat cukup tinggi, terlihat dari keterlibatan mereka bekerja bersama-sama membersihkan lingkungan sekitar. Hal mana disambut dengan antusias oleh aparat kampung, karena menjelang HUT Kemerdekaan RI, tanggal 17 Agustus diselenggarakan juga lomba kebersihan kampung di lingkungan Kabupaten Tambrauw. Anak-anak yang berpartisipasi dalam kegiatan ini, setiap pagi harus membersihkan halaman rumah dan membuang sampah pada tempatnya serta menggosok gigi sebelum ke sekolah. Dukungan penuh dari keluarga sangat diperlukan agar kegiatan ini terus berkelanjutan.

\subsection{Pendidikan Konservasi Penyu belimbing}

Kegiatan ini disinkronkan dengan bidang pendidikan, karena dalam menunjang program konservasi pola pikir anak-anak perlu dibentuk untuk memahami pentingnya menjaga kelestarian hewan langka ini yang juga merupakan ikon kabupaten Tambrauw. Kegiatan ini dilakukan bersama dalam bentuk "Kemah Sahabat Penyu" yang pelaksanaannya berlangsung dari tanggal 1-3 Agustus 2016 (Gambar 3.6). 


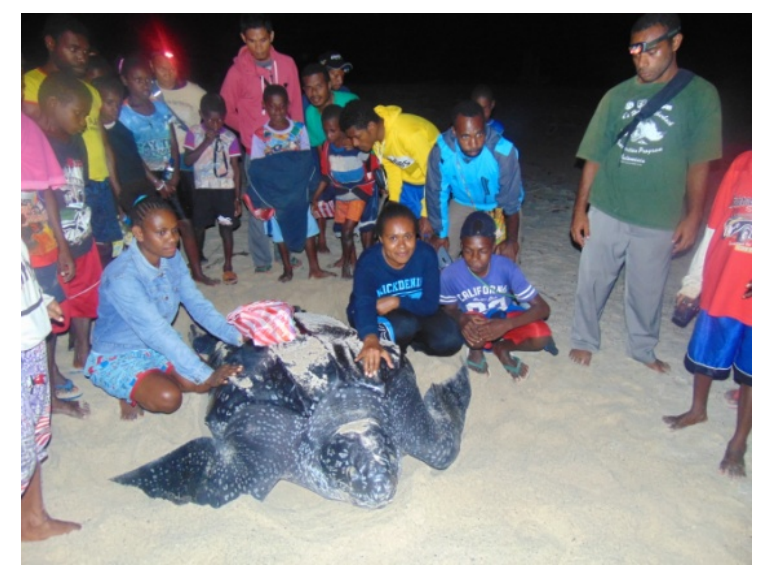

Gambar 3.6. Suasana Kemah Sahabat Penyu sebagai media pelaksanaan pendidikan konservasi Penyu belimbing (Dermochelys coriacea) bagi anak-anak.

Sebanyak 29 orang anak beserta dengan tim pendamping dari UNIPA ikut terlibat dalam kegiatan ini. Dalam kegiatan ini anak-anak diperkenalkan dengan jenis penyu serta habitat peneluran di sepanjang pantai Wermon dan Jamursba Medi (Hitipeuw dkk., 2007). Supaya suasana menarik dan memotivasi anak-anak untuk memahami program konservasi, kombinasi rangakaian permainan dan pembelajaran dilakukan sehingga memudahkan anak-anak mengerti tujuan pelaksanaan kegiatan ini. Hal yang mendukung pelaksanaan program ini karena masyarakat setempat memiliki pemahaman yang sangat kuat sekaligus komitmen untuk menjaga kelestarian sumberdaya alam melalui aturan tidak tertulis yang diwariskan dari generasi ke generasi (Pattiselanno dkk., 2013).

\section{KESIMPULAN DAN SARAN}

Tanggapan positif masyarakat terhadap program KKN menunjukan bahwa program pendidikan yang menyentuh langsung kebutuhan masyarakat sangat diperlukan untuk menunjang pemberdayaan masyarakat di Pesisir Kepala Burung Papua. Kegiatan ini bernilai positif dalam menunjang penyelenggaraan konservasi penyu belimbing di Saubeba.

Dukungan langsung pemerintah daerah yaitu dengan memberikan kesempatan mahasiswa untuk melakukan KKN serta ikut membantu program kerja yang relevan dengan rencana kerja Satuan Kerja Pemerintah Daerah (SKPD) di tingkat kampong perlu dilakukan secara berkelanjutan.

\section{UCAPAN TERIMAKASIH}

Lembaga Penelitian dan Pengabdian Pada Masyarakat Universitas Papua melalui Divisi Pembangunan Berkelanjutan telah membantu selama pelaksanaan program KKN di Saubeba.

\section{DAFTAR PUSTAKA}

Hitipeuw, C., P. Dutton, S. Benson, J. Thebu, and J. Bakarbessy (2007). Population status and internesting movement of leatherback turtles, Dermochelys coriacea, nesting on the northwest coast of Papua, Indonesia. Chelonian Conservation and Biology 6, 28-36.

Pakiding, F., R. Bawole, A. Wospakrik, J. Tangke Allo, S. Keroman, K. Zohar, dan D. Lontoh. (2016). Desa Membangun Untuk Konservasi: Belajar dari Distrik Abun, Kabupaten Tambrauw Propinsi Papua Barat, Lembaga Penelitian dan Pengabdian Pada Masyarakat Universitas Papua, Manokwari. 
Pattiselanno, F., A. Wondikbo, A. Emaury, A. Farwas, I. Rumayomi, dan N. Towansiba. 2016. Pengabdian Pada Masyarakat di Pesisir Kepala Burung: Pembelajaran dari Kampung Saubeba di Tambrauw, Provinsi Papua Barat. Makalah disampaikan dalam Seminar Nasional Lahan Basah, 5 November 2016, LPPM Universitas Lambung Mangkurat.

Pattiselanno, F. (2014). Why bother about marine protected areas? Jakarta Post, 28 June 2014

Pattiselanno, F., Y. Burako, B. Maryen, K. Zohar dan S. Wairara. (2013). "Bur, Nden, Mikindewa, Membow" Tanah, hutan dan laut dilindungi untuk hari depan: Sebuah pembelajaran tentang kearifan tradisional masyarakat Distrik Abun, Kabupaten Sorong, Papua. Warta Konservasi Lahan Basah 21(1): $4,5,17$ 